\title{
Salicylic Acid Triggers Adaptation Cadmium Cytogenetic Toxicity in Roots of Nigella sativa $\mathbf{L}$
}

\author{
A.A. El-Ghamery and M.A. Mousa ${ }^{\#}$ \\ Botany and Microbiology Department, Faculty of Science (Boys), Al-Azhar University, \\ Cairo, Egypt.
}

\begin{abstract}
CADMIUM (Cd) is a toxic heavy-metal pollutant in the environment, it is a nonessential element, which strongly inhibits plant growth and development, and causes plant death even at very low concentrations. Root tip cells of Nigella sativa were separately treated with different concentrations $(5,10,25$ and 50ppm) of cadmium for 3, 6, 12 and $24 \mathrm{~h}$ and the results were recorded. The results showed that all concentrations of cadmium reduced the mitotic index and caused a disturbance in the frequencies of mitotic phases. The treatment with 50ppm of metal for $24 \mathrm{~h}$ was the most effective in reducing the mitotic activity and inducing the highest percentage of mitotic abnormalities. The different types of abnormalities were irregulatries, bridges, sickness at different phases, disturbed chromosomes or bi nucleated cells, forward and lagging chromosomes. Also, in this study three concentrations of SA $(0.01,0.1$ and $0.2 \mathrm{mM})$ for 6 and $12 \mathrm{~h}$ were used to recover the cytotoxicity of the cadmium treatment (50ppm for 3 and 24h). This Post treatment with SA resulted in increasing MI and significant reduction of chromosomal abnormalities. These results illustrate the ameliorating effect of SA under stress conditions and reveal that SA is effective in alleviating the toxic effects of heavy metals at all applied concentrations.
\end{abstract}

Keyword: Cadmium (Cd), Heavy metals, Salicylic acid (SA), Nigella sativa (N. sativa), Mitotic activity (MI), Chromosomal aberrations(CAs).

\section{Introduction}

Cadmium $(\mathrm{Cd})$ is non-essential nutrient elements but toxic heavy metal for biology, especially at high concentrations in soil (Schutzendubel et al., 2001; He et al., 2011 and Rascio \& NavariIzzo, 2011). The cadmium (Cd) level in soil and aquatic environments is increasing with intensive anthropogenic activities, including industrial, agricultural and/or urban development (Li et al., 2012). Cd can be taken up by roots and accumulate at high concentrations in plant tissues (Irfan et al., 2014). This heavy metal, which most likely enters the cell through the existing mineral uptake machinery, also constitutes a serious threat to human health (Lin \& Aarts, 2012). Increasing concentrations of $\mathrm{Cd}$ in soils represent a threat to plants because of its mobility and phytotoxicity (Wahid et al., 2010). Cadmium may limit plant growth and induce numerous physiological and metabolic disturbances, both at the whole plant and cellular levels. It is well documented that $\mathrm{Cd}$ exposure, for example, can cause growth inhibition related to reduction of mitotic activity, induction of chromosome disorders and nuclear abnormalities in the apical meristems (Liu et al., 2003/2004; Unyayar et al., 2006; Zhang et al., 2009; Qin et al., 2010; Aslam et al., 2014 and Wang et al., 2014). Cd was found to decrease the mitotic index (MI) and induced chromosomal aberrations and micronucleus (MN) formation (El-Ghamery et al., 2001; Aslam et al., 2014 and Wang et al., 2014 and 2016).

In plants, cadmium is an easily absorbed and rapidly translocated heavy metal and causes strong toxicity even at relatively low concentrations (Das, et al 1997). Cadmium characteristically inhibits root growth and cell division in plants such as Allium cepa, tradescantia, Vicia faba

\#Corresponding author email: ma mousa@azhar.edu.eg

DOI: 10.21608 /ejbo.2018.3049.1159

C2018 National Information and Documentation Centre (NIDOC) 
(Steinkellner et al., 1998), Nicotiana tabacum (Fojtova \& Kovarik, 2000). Cd damages the nucleoli in cells of root tip (Nolan et al., 2003 and Wang et al., 2016) and inhibits the DNA repair mechanism (Rossman et al., 1992 and Wang et al., 2014). Numerous experimental studies have shown the genotoxicity of $\mathrm{Cd}$ salts (Seoane \& Dulout, 2001). Cd induces clastogenic and genotoxic disturbance in plants (Seoane \& Dulout, 2001) and inhibits root growth and cell division in different plants (Fojtova \& Kovarik, 2000). The possible pathways of $\mathrm{Cd}$-induced genotoxicity may involve the interaction of the metal with DNA and damage the DNA, either directly or indirectly (Valverde et al., 2001 and Bezrukova et al., 2016). At physiological level, Cd directly or indirectly induces reactive oxygen species (ROS) which affects the redox status of the cell and causes oxidative damage to proteins, lipids and other biomolecules (Stohs et al., 2000 and Schützendübel et al., 2001).

Salicylic acid (SA) is a compound that is chemically like aspirin. It functions as a phytohormone, an important factor in environmental stress tolerance in plants (Bosch et al., 2007). Salicylic acid (SA) is an essential component of plant resistance to pathogens and also plays an important role in mediating plant responses to some abiotic stresses (He et al., 2010). The application of SA may either be harmful or provide protection during abiotic stress, depending on the plant species, concentration and the mode of application (Horváth et al., 2007). The ameliorating effect of SA treatment on seed germination and seedling growth was also shown during $\mathrm{Pb}^{2+}$ or $\mathrm{Hg}^{2+}$ stress in rice (Mishra et al., 1997). Later, much more attention was attracted by the role of SA in Cd tolerance (Krantev et al., 2008 and Popova et al., 2009). SA produces an ameliorative protective effect in plants in response to abiotic stress, such as metal toxicity, heat, chilling, osmotic and salt stress (Borsani et al., 2001; Janda et al., 2001.; Singh \& Usha, 2003.; Wang \& Li, 2006; Gunes et al., 2007; He \& Zhu, 2008; Szepesi et al., 2008; Ivanova et al., 2008; Popova et al., 2009 and Gondor et al., 2016) and drought (Bechtold et al., 2010). SA also elevates negative action of the stress-inducing factors (Horvath et al., 2007 and Hayat et al., 2010). The considerable interests have been focused on SA due to its ability to induce a protective measure on plant under stress factors (Sakhabutdinova et al., 2003). Exogenous SA application may be responsible for activation of defense genes (El-Tayeb et al., 2006) and it is supposed that exogenous SA as antioxidants may have wider application as means for the simultaneously increasing resistance not to one but to several stress-inducing factors. SA may be applied in agriculture for increasing the plant production quality. The majority using the SA as protective agent before the treatment plant with abiotic factor as recorded by many investigators (Umebese et al., 2013; Jyothsna \& Murthy, 2016 and Abdul Halim \& Phang, 2017). This work deals with the effect of cadmium chloride on the course of mitosis and on cell divisions in Nigella sativa (black seed) root tip meristem cells as well as with protective effect of SA on these processes.

\section{Materials and Methods}

In this investigation Nigella sativa $(2 \mathrm{n}=12)$ plant used as test plant. This plant considered to be a good material for cytological studies as it has relatively low number of chromosomes of suitable sizes with good stain ability and a marker telocentric. The seeds were kept soaked for some time in distilled water followed by Sodium hypochloride solution for $2 \mathrm{~min}$. Thereafter the seeds were thoroughly washed with running water. Presoaked seeds were allowed to germinate.

\section{To study the toxic effect of cadmium}

Ten germinated seeds of Nigella sativa with radicle $2-3 \mathrm{~cm}$ length, were treated with different concentrations of $\mathrm{CdCl}_{2}(5,10,25$ and 50ppm) for $3,6,12$ and $24 \mathrm{~h}$. Control germinated seeds were placed in distilled water.

\section{To study the effect of salicylic acid}

Ten germinated seeds of Nigella sativa with radicle $2-3 \mathrm{~cm}$ length, were treated with different concentrations of salicylic acid $(0.0,0.01$, and $0.2 \mathrm{mM}$ ) for 6 and $12 \mathrm{~h}$. Control germinated seeds were placed in distilled water.

To study the recovering effects of cadmium by salicylic acid $\left(\mathrm{C}_{7} \mathrm{H}_{6} \mathrm{O}_{3}\right)$

Root tip cells were treated with $50 \mathrm{ppm}$ concentration of cadmium for 3 and $24 \mathrm{~h}$ soaked in different concentrations of salicylic acid (SA) $(0.0$, 0.01 , and $0.2 \mathrm{mM}$ ) for 6 and $12 \mathrm{~h}$.

\section{Mitotic preparation}

After each of the three treatments (1, 2 and 3), the roots were cut off and immediately fixed in glacial acetic acid: absolute ethyl alcohol $(1: 3 \mathrm{v} / \mathrm{v})$ 
for overnight (Qian, 2004). Root tips were stained by using the Feulgen squash technique (Darlington \& La Cour, 1976). At least three slides for each treatment were examined to determine the mitotic index (MI), and the frequency of mitotic phases. Dividing cells in the same slides were analyzed for determination of the percentage of different types of abnormalities and their total percentages of abnormalities were also calculated.

\section{Statistical analysis}

Each treatment was made in three replicates. For statistical analysis, one-way ANOVA (Sigma Plot13.0 software) SPSS was used to determine significance at $\mathrm{P}<0.05$ (Duncan, 1955).

\section{Results}

The effects of different concentrations of $\mathrm{CdCl}_{2}$ $(5,10,25$, and $50 \mathrm{ppm})$ for different durations $(3$, 6,12 and 24h) on mitotic index of Nigella sativa L. given in Table 1 and represented in Fig.1. In general, the mitotic index values reduced in the treated roots was a dose and time dependent increased with increasing concentrations from 5 to $50 \mathrm{ppm}$. It was also observed that, with the same concentration, mitotic index decreased with prolonging treatment period. Thus, after the treatment with $50 \mathrm{ppm}$ concentration at $24 \mathrm{~h}$ the mitotic index reached to the lowest value of $4.75 \%$ compared the control value of $13.41 \%$. Also, the results in Table 1 showed that the percentage of each mitotic phase in treated root tips of $N$. sativa $\mathrm{L}$ was changed following the treatments with the $\mathrm{CdCl}_{2}$ and did not depend on concentration and time of treatment. The results in Table 2 and Fig. 2 showed the percentages of total abnormal mitotic cells induced in treated root tips increased with increasing treatment times and concentrations and the total percentage of abnormalities at prophase stage was higher than those at the other mitotic stages. The total percentage of abnormalities induced at metaphase was higher than that in anaphase and telophase for all treatments. In the same manner, the total percentage of abnormalities induced at anaphase stage was higher than that present in telophase for all treatments.

TABLE 1. Mitotic index and mitotic phases of $N$. sativa $L$. meristematic cells exposed to different concentrations of cadmium chloride after 3, 6, 12 and 24 hours.

\begin{tabular}{|c|c|c|c|c|c|c|c|}
\hline \multicolumn{2}{|c|}{ Treatments } & \multirow{2}{*}{$\begin{array}{l}\text { Counted } \\
\text { cells }\end{array}$} & \multirow{2}{*}{$\begin{array}{c}\text { Mitotic index } \\
\quad(\mathrm{MI} \pm \text { S.E })\end{array}$} & \multicolumn{4}{|c|}{ Mitotic phases \% } \\
\hline $\begin{array}{l}\text { Time } \\
\text { (h) }\end{array}$ & $\begin{array}{l}\text { Conc. } \\
(\mathbf{p p m})\end{array}$ & & & Prophase & Metaphase & Anaphase & Telophase \\
\hline \multirow{5}{*}{3} & Control & 1680 & $13.39 \pm 0.3$ & 48.88 & 22.23 & 15.55 & 13.34 \\
\hline & 5 & 1668 & $13.19 \pm 0.06$ & 49.54 & 23.64 & 14.09 & 12.73 \\
\hline & 10 & 1660 & $12.65 \pm 0.04$ & 50.95 & 24.28 & 13.34 & 11.43 \\
\hline & 25 & 1645 & $12.15 \pm 0.08^{*}$ & 51.50 & 24.50 & 13.00 & 11.00 \\
\hline & 50 & 1635 & $11.31 \pm 0.02 *$ & 54.05 & 25.40 & 11.90 & 8.65 \\
\hline \multirow{5}{*}{6} & Control & 1695 & $13.57 \pm 0.5$ & 49.56 & 23.92 & 15.22 & 11.30 \\
\hline & 5 & 1678 & $12.81 \pm 0.03$ & 51.17 & 24.65 & 13.95 & 10.23 \\
\hline & 10 & 1650 & $11.82 \pm 0.02 *$ & 53.33 & 25.64 & 11.28 & 9.75 \\
\hline & 25 & 1625 & $10.09 \pm 0.05^{*}$ & 57.93 & 27.44 & 9.15 & 5.48 \\
\hline & 50 & 1610 & $9.19 \pm 0.01 *$ & 59.46 & 27.70 & 8.78 & 4.06 \\
\hline \multirow{5}{*}{12} & Control & 1675 & $13.25 \pm 0.01$ & 50.45 & 21.62 & 14.86 & 13.06 \\
\hline & 5 & 1655 & $11.84 \pm 0.02$ & 53.57 & 22.96 & 12.75 & 10.72 \\
\hline & 10 & 1630 & $10.12 \pm 0.05^{*}$ & 56.36 & 24.25 & 10.30 & 9.09 \\
\hline & 25 & 1615 & $9.10 \pm 0.03 *$ & 57.82 & 25.85 & 8.85 & 7.48 \\
\hline & & 1600 & $6.56 \pm 0.05^{*}$ & 61.90 & 28.57 & 5.73 & 3.80 \\
\hline \multirow{5}{*}{24} & Control & 1670 & $13.41 \pm 0.06$ & 51.35 & 21.87 & 14.28 & 12.50 \\
\hline & 5 & 1650 & $10.30 \pm 0.01 *$ & 55.29 & 23.53 & 11.76 & 9.42 \\
\hline & 10 & 1620 & $8.02 \pm 0.04 *$ & 57.70 & 26.92 & 8.46 & 6.92 \\
\hline & 25 & 1590 & $6.28 \pm 0.05^{* *}$ & 60.00 & 28.00 & 7.00 & 5.00 \\
\hline & 50 & 1580 & $4.75 \pm 0.03^{* *}$ & 64.00 & 29.33 & 4.00 & 2.67 \\
\hline
\end{tabular}

S.E., Standard error; * Significant at $5 \%$ level $(\mathrm{P} \leq 0.05) ; *$ Significant at $1 \%$ level $(\mathrm{P} \leq 0.01)$. 


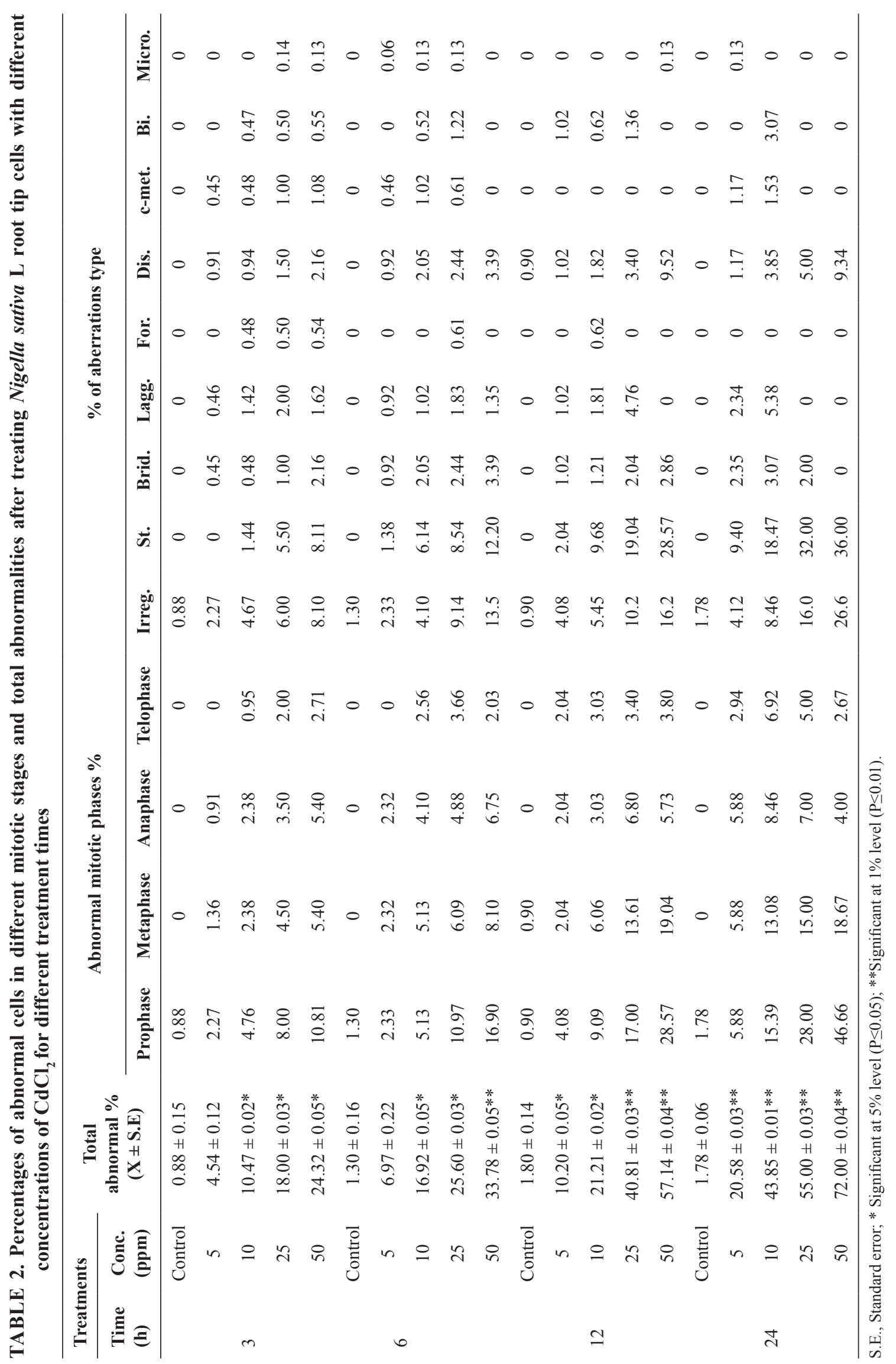

Egypt. J. Bot. 58, No. 2 (2018) 


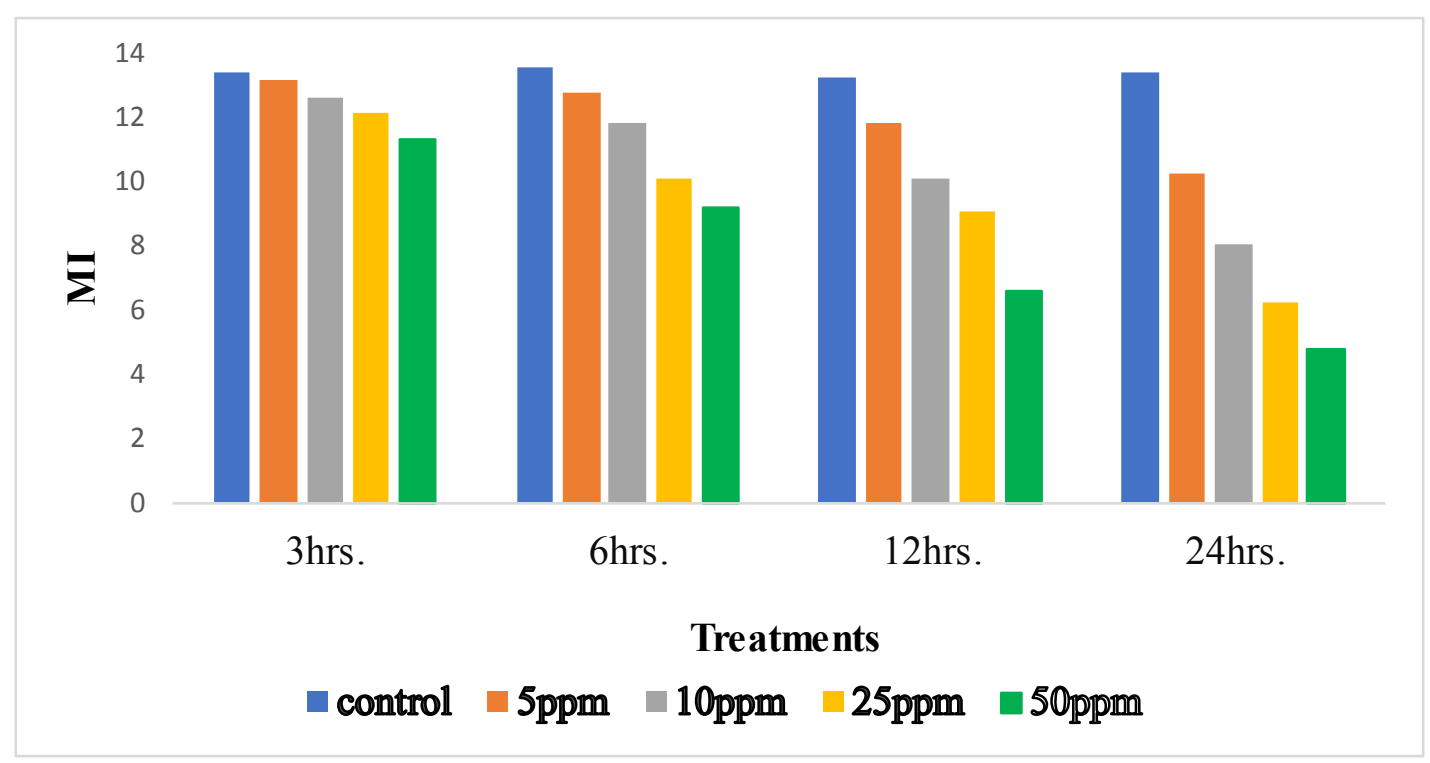

Fig. 1. Diagrammatic representation effect of different concentrations (5 to $50 \mathrm{ppm}$ ) of $\mathrm{CdCl}_{2}$ on mitotic index of Nigella sativa $\mathrm{L}$. seeds after four treatment periods $(3,6,12$ and $24 \mathrm{~h})$.

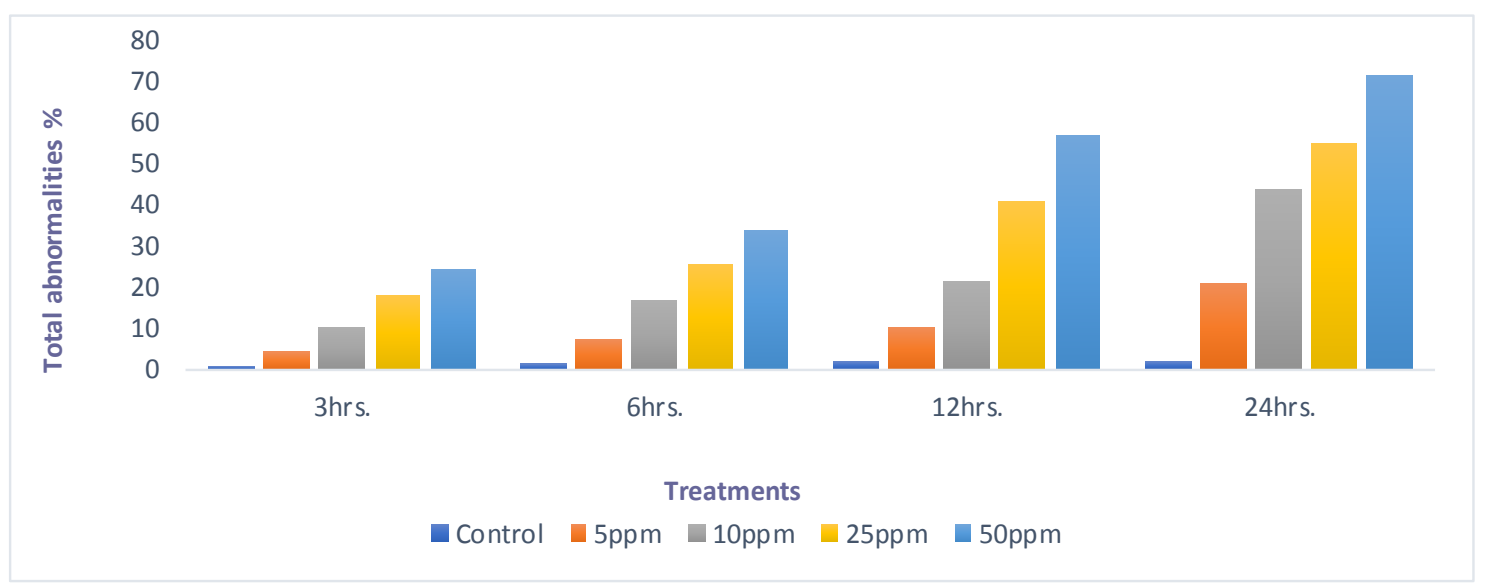

Fig. 2. Effect of different concentrations $(5$ to $50 \mathrm{ppm})$ of $\mathrm{CdCl}_{2}$ on total abnormal cells of Nigella sativa seeds after four treatment periods $(3,6,12$ and $24 \mathrm{~h})$.

Cadmium induced irregular prophase, disturbed metaphases, c-metaphase, chromosome bridges, chromosome stickiness, laggards, forward chromosome, bi-nucleated cell and micronuclei, which are biomarkers of genotoxic events and chromosomal instability (Table 2 and Fig. 3 \{1$15\})$.

In this study the results showed that, all concentrations of using SA caused an increased in $\mathrm{MI}$ in treated root tips compared with untreated root tip cells (control) for each period. This increase more clearly at the concentration $(0.01 \mathrm{mM})$, when MI recorded was 15.05 and 14.86 for 6 and $12 \mathrm{~h}$, respectively. Also, all applied concentrations of SA caused elevate in total abnormal cells percentages and the concentration $(0.1 \mathrm{mM})$ was the lowest one and caused minimal increase in total abnormalities percentage in treated root tip cells. (Table 3).

Result presented in Table 4 clearly state that, using SA post-treatment caused a significant increase of $\mathrm{MI}$ at high concentrations $(0.1-0.2 \mathrm{mM})$ in all treated root tip cells. The improvement was more prevalent at higher concentrations of SA in root tips treated with $\mathrm{CdCl}_{2}$ for $24 \mathrm{~h}$. On contrast, the lower concentration of SA $(0.01 \mathrm{mM})$ for both duration of recovery caused a non-significant increase of $\mathrm{MI}$ in treated cells with $\mathrm{CdCl}_{2}$ for $3 \mathrm{~h}$, and for $24 \mathrm{~h}$. 


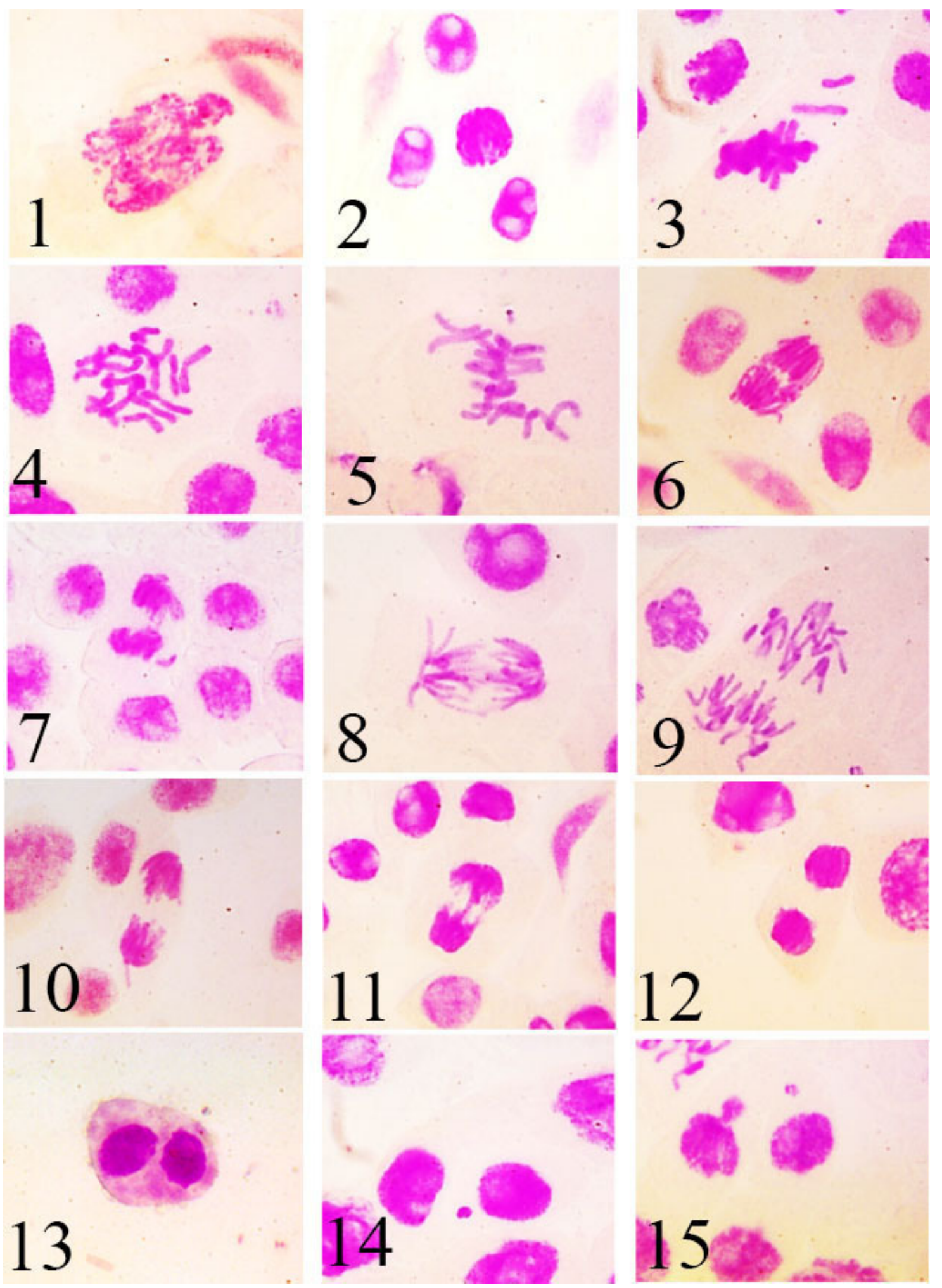

Fig. 3. Chromosome and cellular aberrations observed in $N$. sativa $\mathrm{L}$ root meristem exposed to $\mathrm{CdCl}_{2}$. (1) Irregular prophase, (2) Sticky prophase, (3) Un-oriented chromosomes, (4) C- metaphase, (5) Disturbed metaphase, (6) Bridges at anaphase, (7) Anaphase with chromatinal bridge and lagging chromosome, (8) Anaphase with multi bridge and forward chromosomes, (9) Disturbed anaphase, (10) Late anaphase, (11) Sticky anaphase with broken bridge, (12) Sticky telophase, (13) Bi nucleated cell, (14) Micronucleus and (15) Two cell with micronucleus. 
TABLE 3. Effect of different concentration of salicylic acid on $N$. sativa $L$ root tip cells for different durations.

\begin{tabular}{|c|c|c|c|c|c|c|c|c|}
\hline \multirow{3}{*}{ Treatments } & \multicolumn{8}{|c|}{ Salicylic acid concentrations (mM) } \\
\hline & \multicolumn{4}{|c|}{$6 \mathbf{h}$} & \multicolumn{4}{|c|}{$12 \mathrm{~h}$} \\
\hline & Cont. & 0.01 & 0.1 & 0.2 & Cont. & 0.01 & 0.1 & 0.2 \\
\hline Mitotic index & 13.02 & $15.05^{*}$ & $14.11^{*}$ & 13.68 & 13.42 & $14.86^{*}$ & $14.63^{*}$ & $13.81^{*}$ \\
\hline Total abn. $\%$ & 0.44 & $4.18^{*}$ & 2.67 & 3.18 & 0.50 & $6.25^{*}$ & 3.83 & $5.02^{*}$ \\
\hline
\end{tabular}

TABLE 4. Effect of different concentration of salicylic acid on treated cells of $N$. sativa $L$ with cadmium chloride (50ppm) for different durations.

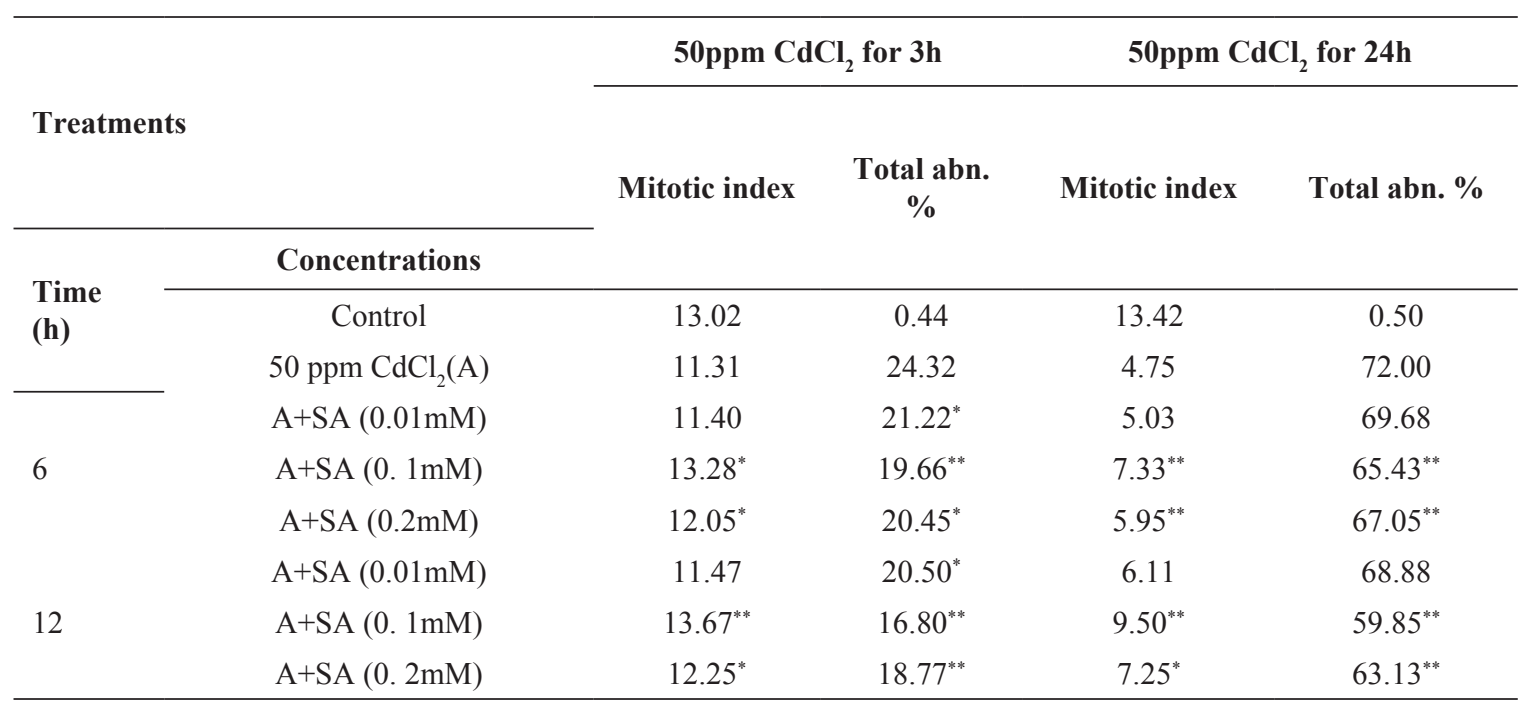

S.E., standard error; * Significant at $5 \%$ level $(\mathrm{P} \leq 0.05) ; * *$ Significant at $1 \%$ level $(\mathrm{P} \leq 0.01)$.

Application of SA after $\mathrm{CdCl}_{2}$ exposure resulted in the significant reduction of chromosomal abnormalities as shown in the Table 4. In treated cells with $\mathrm{CdCl}_{2}$ for $3 \mathrm{~h}$, the recovery with SA for $6 \mathrm{~h}$, caused more than $10 \%$ decrease in CAs at 0.01 when the total abnormalities values were $21.22 \%$ compared with treated root tips of $24.32 \%$ but, the recovery with SA for $12 \mathrm{~h}$, caused more than $15 \%$ decrease in CAs at 0.01 when the total abnormalities values were $20.50 \%$. In the same manner, the results showed greatest adaptive response to SA 0.1 and $0.2 \mathrm{mM}$ concentrations at which, SA caused more than $20 \%$ decrease in CAs in the root tip cells. Also, treated cells with $\mathrm{CdCl}_{2}$ for $24 \mathrm{~h}$, the recovery with SA caused maximum decreased in CAs (more than $10 \%$ ) at $0.1 \mathrm{Mm}$ concentration of both duration of recovery.

\section{Discussion}

Cadmium (Cd) is a strong environmental pollutant with high toxicity to animals and plants.
Positive results monitored in higher plant like the $N$. sativa indicate the presence of cytotoxic and/or genotoxic attributes of some heavy metals such as $\mathrm{Cd}$. This can also be used to monitor ameliorative and protective effects of some other compounds such antioxidants.

In this study, the results revealed the different concentrations of cadmium applied for different periods caused a reduction in the MI values. This effect a time and a dose dependent. Similar effects of cadmium on the MI were reported in different plants such as in Lactuca sativa, Eruca sativa and Coriaudrum sativum (El-Ghamery et al., 2001), Phaseolus vulgaris (Çavusoğlu et al., 2009), in Lens culinaris (Kiran \& Şahin, 2006), Pisum sativum (Fusconi et al., 2007), Triticum aestivum (Bezrukova et al., 2016), Capsicum annuum (Aslam et al., 2014), Vigna radiatae (Munee et al., 2011), Vigna unguiculata (Thangaraja et al., 2013) Vicia faba (Li \& Zheng, 1992; George, 2000; ElAshry et al., 2012 and Arya \& Mukherjea 2014), 
in Allium cepa (Zou et al., 2012; Wang et al., 2014 and 2016 and Nataliya, 2015) and Hordeum vulgare (Shi et al., 2017). The decline of MI suggested that the $\mathrm{Cd}$ could prevent cells from going into cell division (Unyayar et al., 2006). In the same manner Seth et al. (2008) suggested that exposure to $\mathrm{Cd}$ prevented cells entering cell division phases, which then resulted in a decrease in MI. The reduction of MI in treated roots is probably due to disturbances in the cell cycle as well as chromatin function, which is induced by interactions between DNA and the heavy metal used (Çavusoğlu et al., 2009 and Wang et al., 2014). In this concern, Thangaraja et al. (2013) reported that the decrease in mitotic index is a result of cytotoxic effects.

The analysis for the number of cells in each phase of mitosis showed change in root treated with cadmium compared with untreated roots which causing accumulation cells at prophase and metaphase stages. In this respect, Bezrukova et al. (2016) reported that, decrease in cells at anatelophase reflecting a reduction in MI and cadmium induces cell cycle checkpoints defects in the tested plant root tip cells.

The experimental findings of the present study showed that $\mathrm{CdCl}_{2}$ can induce significant chromosomal abnormalities in the root meristem cells of Nigella sativa $\mathrm{L}$ as compared to control, indicates the genotoxic potential of heavy metal used. The results are in agreement with the results recorded in other plants by many investigators such as Li \& Zheng (1992), George (2000), Kiran \& Şahin (2006), Fusconi et al. (2007), Çavusoğlu et al. (2009), Munee et al. (2011), El-Ashry et al. (2012), Zou et al. (2012), Thangaraja et al. (2013), Aslam et al. (2014), Wang et al. (2014 and 2016), Nataliya (2015), Bezrukova et al. (2016) and Shi et al. (2017). They demonstrated the potential cytotoxic and genotoxic of cadmium in their tested plants meristematic cells exposed to different concentrations of cadmium. The aberrant mitotic stages might have been the outcome of spindle poisoning that cause chromosome disturbances during mitotic cell division (Zou et al., 2012). The total percentages of the abnormalities increased gradually with increase the heavy metal concentration and as the time of treatment prolonged. In general, the highest percentages of abnormalities induced by the $\mathrm{CdCl}_{2}$ in all treatments were recorded in divided cells at prophase and metaphase stages in tested plant.
Different types of mitotic abnormalities were observed in Nigella sativa $\mathrm{L}$ root tip cells after treatments with $\mathrm{CdCl}_{2}$. The variation in the percentages of chromosomal aberration in this study was recorded and the total abnormalities previously rapidly by increasing the concentration (El-Ashry et al., 2012; Zou et al., 2012; Thangaraja et al., 2013; Wang et al., 2014 and 2016; Aslam et al., 2014; Nataliya, 2015; Bezrukova et al., 2016 and Shi et al., 2017). In Nigella sativa L these types were: Irregular prophase, stickiness at different phases, disturbed metaphase, C- metaphase, bridges, forward chromosome and lagging in addition to other types recorded in low frequency in some treatments such as bi-nucleated cells and micronucleus. Of these types of aberrations, stickiness, as a most frequent type, was recorded in the different mitotic phases in root tip cells of tested plant treated with $\mathrm{CdCl}_{2}$. This type of abnormality was recorded by many investigators following the treatment of different plants by cadmium (Zou et al., 2012; Wang et al., 2014 and 2016; Aslam et al., 2014 and Bezrukova et al., 2016).

In this study, in forms of irregular prophase (Fig. $3\{1\}$ ), where the DNA in chromatin threads may be despiraled and/or depolarized or the chromatin threads were not typically arranged, was a common type of abnormalities induced in treated root tip cells $N$. sativa $\mathrm{L}$ by heavy metal used and was recorded in a relatively high percentage in all treatments. The percentage of irregular prophase were higher than those in other types of stages. Formation of irregular prophase resulted from the its effect on the process of individualization of chromatin threads to normal chromosomes as stated by (Wang et al., 2014). The induction of sticky chromosomes (Fig. $3\{11$ and 12$\}$ ), indicates the toxic effect of cadmium on the organization of chromatin. This property is related to a disturbed balance of histones or other proteins that are responsible for controlling the proper structure of nuclear chromatin; generally, this imbalance leads irreversibly to cell death (El-Ghamery et al., 2003). Also, the induction of sticky chromosomes and laggard chromosomes (Fig. $3\{7\}$ ), are indicators of spindle poisoning (Onyemaobi et al., 2012). Bridges at anaphase (Fig. $3\{6$ and 8$\}$ ), can result from the terminal deletion or loss of telomeres. According to suggestion of El-Ghamery et al. (2003), chromosomal bridge could be a result of the failure of free anaphase separation, unequal translocation or inversion of chromosome segments. 
The abnormal C-metaphases (Fig. $3\{4\}$ ) were formed because of the complete inactivation of division of the spindle (Fernandes et al., 2007). Consequently, arrest of cells in metaphase stage might be one of the causes of mitotic inhibition. C-metaphase induction could be due to inactivation of spindle followed by random scattering of chromosomes. The C-metaphase that we observed in treated meristems suggests that $\mathrm{Cdcl}_{2}$ act on the mitotic spindle apparatus, probably interfering with the polymerization and depolymerization of microtubules (Seth et al., 2008).

Inhibition of cytokinesis following telophase was responsible for bi-nucleated cell formation visible in the next interphase of a new cell cycle (Fig. $3\{13\}$ ). Some authors suggested that phragmoplast inhibition at the early stage of telophase is the responsible disturbance for binucleated cell formation (Fiskesjö, 1997; Rank et al., 2002 and Majewska et al., 2003).

Micronuclei (Fig. $3\{14$ and 15\}) were observed after $\mathrm{Cd}$ treatments. The formation of micronucleus implies that $\mathrm{CdCl}_{2}$ causes damage to DNA (Gabara et al., 1995 and Fusconi et al., 2007). Micronucleus can be derived from acentric fragments involving clastogenic activity, or from entire chromosomes involving aneugenic activity. This means that $\mathrm{Cd}$ is clastogens that induce chromosome breaks and/or aneugens explaining lagging chromosomes. This results in Similar with Fusconie et al. (2007) and Wang et al. (2014 and 2016). They recorded micronuclei formation following treatments their tested plants with cadmium.

Forward chromosome(s) (Fig. $3\{8\}$ ) have been described as a weak $\mathrm{C}$-mitotic effects indicating risk of aneuploidy (Fiskesjö, 1985 and 1988). In this type, the arms of chromosomes pointed outward to the pole instead of centromere during the chromosome movement at ana-telophases.

SA complete growth inducing properties are reported barley roots under $\mathrm{Cd}$ treatment (Matewally et al., 2003). The inhibition of growth under $\mathrm{Cd}$ treatment could be due to the inhibition of cell division and elongation rate of cells that mainly occurs by an irreversible inhibition proton pump responsible for the process (Liu et al., 2003/2004). In this investigation the results showed that, all concentrations of using SA caused an increase in MI to a highest value of MI 15.05 which recorded by $0.01 \mathrm{mM}$ concentration for $6 \mathrm{~h}$ compared with control value of 13.03 . This observation contrasted with the results obtained by Mahfouz et al. (2014) which demonstrated a dose dependent decreased in MI of Allium cepa treated with different concentration of SA for different durations treatments. In this respect, He et al. (2010) reported that mitosis was one of the reasons for growth inhibition in the presence of $\mathrm{Cd}$, and reduction in mitotic index of root tips is a concentration dependent. The pretreatment with SA increased the mitotic index. The increase of the mitotic index under Cd stress by SA pretreatment is probably related to shortening the phases of $\mathrm{G}_{2}$ and prophase or facilitating the abnormal spindle formation ( $\mathrm{He}$ et al., 2008). Also, increased the percentage of total abnormalities in treated root tips to the value of 6.25 compared with the value of control. The results obtained from the present investigation revealed that exogenous SA ameliorate the toxic effect of cadmium chloride. SA has been shown to alleviate the harmful effects of $\mathrm{Cd}$ in maize and pea plants (Krantev et al., 2008, Popova et al., 2009 and Drazic \& Mihailovic, 2005). However, SA can also be a stress factor inducing oxidative stress when its concentration differs from the optimum level. The results obtained by Gondor et al. (2016) were demonstrated that the effect of exogenous SA depends greatly on its form, i.e., whether it is applied as an acid (SA) or a $\mathrm{Na}$ salt (NaSA). The mode of application may also be important, since different combinations may result in fundamentally different effects even at the same concentration.

At cytological level, SA post-treatment resulted in significant decrease in the percentage of cells with chromosomal abnormalities (CAs) from $24.32 \%$ to $19.66 \%$ for $N$. sativa $\mathrm{L}$ treated root tips with cadmium chloride (50ppm) for $3 \mathrm{~h}$ and the period recovery $6 \mathrm{~h}$ and from $72.00 \%$ to $59.85 \%$ for $N$. sativa treated root tips with $\mathrm{CdCl}_{2}$ (50ppm) for $24 \mathrm{~h}$ and the period recovery $12 \mathrm{~h}$ which implies that SA conditioning conferred adaptive response to genotoxic stress of $\mathrm{CdCl}_{2}$. These results are in accordance with the earlier reports demonstrate that, SA-induced protective response to DNA damaging agents (Bautz \& Freese, 1960 and Patra et al., 2005). Earlier results also suggested that SA treatment led to a decrease in oxidative injuries induced by $\mathrm{Cd}$ (Krantev et al., 2008; Popova et al., 2008 and Panda \& Patra, 
2007). The production of $\mathrm{H}_{2} \mathrm{O}_{2}$ during abiotic stress serves as part of the signaling cascade, and increased levels of ROS might interact with SA. Responses to genotoxic stress include activation of distinct stress signaling pathways, delay of cell cycle progression, and induction of DNA repair (Albinsky et al., 1999). The application of SA provide protection during abiotic stress, depending on the plant species, the concentration and the mode of application (Horváth et al., 2007). In contrast, Mahfouz et al. (2014) reported several damages in Vicia faba after application high concentrations of SA.

\section{Conclusion}

The experimental findings from the present study prove that SA is effective in inducing the adaptive response to cytotoxic and genotoxic stress since it significantly enhancement the MI values which decrease under cadmium treatments. Also, all applied concentrations of SA reduces the total percentage of abnormalities induced by the $\mathrm{CdCl}_{2}$. Efforts to understand the different mechanisms by which SA influence biological activities could help to better distinguish the advantages and disadvantages of its use and to clarify its possible protective role against heavy metals.

\section{References}

Abdul Halim, N.I. and Phang, I.C. (2017) Salicylic acid mitigates $\mathrm{Pb}$ stress in Nicotiana tabacum. Galeri Warisan Sains (GWS), 1(1), 16-19.

Albinsky, D., Masson, J.E., Bogucki, A., Afsar, K., Vass, I., Nagy, F. and Paszkowski, J. (1999) Plant responses to genotoxic stress are linked to an $\mathrm{ABA} /$ salinity signaling pathway. Plant. J. 17, 73-82.

Arya, S.K. and Mukherjea, A. (2014) Sensitivity of Allium cepa and Vicia faba towards cadmium toxicity. J. So. Sci. Plant. Nut. 14(2), 474-458.

Aslam, R., Ansari, M.Y.K., Choudhary, S., Bhat, T.M. and Jahan, N. (2014) Genotoxic effects of heavy metal cadmium on growth, biochemical, cytophysiological parameters and detection of DNA polymorphism by RAPD in Capsicum annuиm L. An important spice crop of India. Saudi Journal of Biological Sciences, 21, 465-472.

Bechtold, U., Lawson, T., Mejia-Carranza, J., Meyer, R.C., Brown, I.R., Altmann, T., Ton, J. and
Mullineaux, P.M. (2010) Constitutive salicylic acid defenses do not compromise seed yield, drought tolerance and water productivity in the Arabidopsis accession C24. Plant Cell Environ. 33, 1959-1973.

Bezrukova, M.V., Fatkhutdinova, R.A. and Shakirova, F.M. (2016) Protective effect of wheat germ agglutinin on the course of mitosis in the roots of Triticum aestivum seedlings exposed to cadmium. Russian Journal of Plant Physiology, 63(3), 358364.

Borsani, O., Valpuesta, V. and Botella, M.A. (2001) Evidence for a role of salicylic acid in the oxidative damage generated by $\mathrm{NaCl}$ and osmotic stress in Arabidopsis seedling. J. Plant Physiol. 126, 1024 1030

Bosch, S.M., Penuelas, J. and Liusia, J. (2007) A deficiency in salicylic acid alters isoprenoid accumulation in water-stressed NahG transgenic Arabidopsis plants. Plant Sci. 172(4), 756-762.

Bautz, E. and Freese, E. (1960) Proc. U.S. Nat. Acad. Sci. 46, 1585.

Çavusoğlu, K., Yalçin, E. and Ergene, A. (2009) The cytotoxic effects of zinc and cadmium metal ions on root tip cells of Phaseolus vulgaris L. (Fabaceae). SDU Journal of Science (e-journal), 4(1), 1-11.

Darlington, C.D. and La Cour, L.F. (1976) "The Handling of Chromosomes", (6 ${ }^{\text {th }}$ ed.). L. George Allen and Unwin. Ltd. London, UK.

Das, P., Samantaray, S. and Rout, G.R. (1997) Studies on cadmium toxicity in plants: A review. Environmental Pollution, 98(1), 29-36.

Drazic, G. and Mihailovic, N. (2005) Modification of cadmium toxicity in soybean seedlings by salicylic acid. Plant Sci. 168, 511-517.

Duncan, D.B. (1955) Multiple range and multiple F tests. Biometrics, 11, 1-42.

EL-Ashry, Zeineb M. and Mohamed, Fawzia I. (2012) Protective effects of some antioxidant metals against chromosomal damage induced by cadmium in Vicia faba plant. Int. J. Agric. Res. 7(8), 376-387.

El-Ghamery, A.A., Mansour, M.M. and Abu Seidah, A.A. (2001) The influence of cadmium on the mitotic activity and chromosomal morphology in 
root meristem cells of some Egyptian vegetables. Egyptian Journal of Botany, 41(1), 1-15.

El-Ghamery, A.A., El-Kholy, M.A. and El-Yousser, M.A.A. (2003) Evaluation of cytological effects of $\mathrm{Zn}^{2+}$ in relation to germination and root growth of Nigella sativa L. and Triticum aestivum L. Mutat. Res. 537, 29-41.

El-Tayeb, M.A., El-Enany, A.E. and Ahmed, N.L. (2006) Salicylic acid induced adaptive response to copper stress in sunflower (Helianthus annus). Plant Growth Regul. 50, 191-199.

Fernandes, T.C.C., Mazzeo, D.E.C. and Marin- Morales, M.A. (2007) Mechanism of micronuclei formation in polyploidizated cells of Allium cepa exposed to trifluralin herbicide. Pestic. Biochem. Physiol. 88, 252-259.

Fiskesjö, G. (1985) The Allium test as a standard in environmental monitoring. Hereditas, 102, 99-112.

Fiskesjö, G. (1988) The Allium test-an alternative in environmental studies: The relative toxicity of metal ions. Mutat. Res. 197, 243-260.

Fiskesjo, G. (1997) Allium test for screening chemicals; evaluation of cytological parameters. In: " Plants for Environmental Studies", Wang, W., J.W. Gorsuch and J.S. Hughes (Ed.), pp: 308-333. Lewis, New York, USA.

Fojtova, M. and Kovarik, A. (2000) Genotoxic effect of cadmium is associated with apoptotic changes in tobacco cells. Plant Cell Environ. 23, 531-537.

Fusconi, A., Gallo, C. and Camusso, W. (2007) Effects of cadmium on root apical meristems of Pisum sativum L: Cell viability, cell proliferation and microtubule pattern as suitable markers for assessment of stress pollution. Mutat. Res. 632, 9-19.

Gabara, B., Krajewska, M. and Stecka, E. (1995) Calcium effect on number, dimension and activity of nucleoli in cortex cells of pea (Pisum sativum L) roots after treatment with heavy metals. Plant Science, 111, 153-161.

George, N.M. (2000) Evaluation on mutagenic effects of three heavy metals on Vicia faba. Egypt. J. Genet. Cytol. 31, 37-46.

Gondor, O.K., Pál, M., Darkó, É., Janda, T. and Szalai, G.
(2016) Salicylic acid and sodium salicylate alleviate cadmium toxicity to different extents in maize (Zea mays L). PLoS ONE, 11(8), 1-18.

Gunes, A., Inal, A., Alpaslan, M., Eraslan, F., Bagci, E.G. and Cicek, N. (2007) Salicylic acid induced changes on some physiological parameters symptomatic for oxidative stress and mineral nutrition in maize ( $\mathrm{Zea}$ mays L) grown under salinity. J. Plant Physiol. 164, 728-736.

Hayat, Q., Hayat, S., Irfan, M. and Ahmad, A. (2010) Effect of exogenous salicylic acid under changing environment: A review. Environ. Exp. Bot. 68, 1425.

He, J.Y., Ren, Y.F., Zhu, C. and Jiang, D.A. (2008) Effects of cadmium stress on seed germination, seedlings growth and amylase activities in rice. Chinese J. Rice Sci. 22, 409-414.

He, J., Ren, Y., Pan, X., Yan, Y., Zhu, C. and Jiang, D. (2010) Salicylic acid alleviates the toxicity effect of cadmium on germination, seedling growth, and amylase activity of rice. J. Plant Nutr. Soil Sci. 173, 300-305.

He, J., Qin, J., Long, L., Ma, Y., Li, H., Li, K., Jiang, X., Liu, T., Polle, A., Liang, Z. and Luo, Z.B. (2011) Net cadmium flux and accumulation reveal tissue-specific oxidative stress and detoxification in Populus canescens. Physiologia Plantarum, 143, 50-63.

He, Y. and Zhu, Z.J. (2008) Exogenous salicylic acid alleviates $\mathrm{NaCl}$ toxicity and increases antioxidative enzyme activity in Lycopersicon esculentum. Biol. Plant, 52, 792-795.

Horváth, E., Szalai, G. and Janda, T. (2007) Induction of abiotic stress tolerance by salicylic acid signaling. $J$. Plant Growth Regul. 26, 290-300.

Irfan, M.; Ahmad, A. and Hayat. S. (2014). Effect of cadmium on the growth and antioxidant enzymes in two varieties of Brassica juncea. Saudi Journal of Biological Sciences, 21, 125-131.

Ivanova, A., Krantev, A., Stoynova, Z.H., Popova, L. (2008) Cd-induced changes in lipids of maize plants. Gen. Appl. Plant Physiol. 34, 149-158.

Janda, T., Szalai, G., Tari, I. and Paldi, E. (1999) Hydroponic treatment with salicylic acid decreases 
the effects of chilling injury in maize (Zea mays L) plants. Planta, 208, 175-180.

Jyothsna, P.I. and Murthy, S.D.S. (2016) Review on role of salicylic acid in the alleviation of cadmium induced damage in plants. RJPBCS, 7(4), 27462751.

Kiran, Y. and Şahin, A. (2006) The effects of cadmium on seed germination, root development, and mitotic of root tip cells of lentil (Lens culinaris Medik). World Journal of Agricultural Sciences, 2(2), 196200.

Krantev, A., Yordanova, R., Janda, T., Szalai, G. and Popova, L. (2008) Treatment with salicylic acid decreases the effect of cadmium on photosynthesis in maize plants. J. Plant Physiol. 165, 920-931.

Li, L., Liu, X., Peijnenburg, W.J., Zhao, J., Chen, X., $\mathrm{Yu}$, J. and $\mathrm{Wu}, \mathrm{H}$. (2012) Pathways of cadmium fluxes in the root of the halophyte Suaeda salsa. Ecotoxicology and Environmental Safety, 75, 1-7.

Li, X.L. and Zheng, G.R. (1992) Study on mutagenic effects and antagonism of selenium and cadmium. Carcinog. Teratogen. Mutagen. 4, 19-21.

Lin, Y.F. and Aarts, G.M. (2012) The molecular mechanism of zinc and cadmium stress response in plants. Cellular and Molecular Life Sciences, 69, 3187-3206.

Liu, D., Jiang, W. and Gao, X. (2003/2004) Effects of cadmium on root growth, cell division and nucleoli in root tips of garlic. Biologia Plantarum, 47, 7983.

Mahfouz, H.M., Barakat, H.M., Halem, A.S. and El- Hahdy, M.M. (2014) Effects of Jasmonic and salicylic acids on cell division and cell cycle progression. Egypt. J. Bot. 54(2), 185- 201.

Majewska, A., Wolska, E., Sliwinska, E., Furmanowa, M., Urbanska, N., Pietrosuk, A., Zobel, A. and Kuras, M. (2003) Antimitotic effect, $\mathrm{G}_{2} / \mathrm{M}$ accumulation, chromosomal and ultrastructure changes in meristematic cells of Allium cepa $\mathrm{L}$ root tips treated with the extract from Rhadiola rosea roots. Caryology, 56(3), 337-351.

Matewally, A., Finkemeir, I., George, M. and Dietz, K. J. (2003) Salicylic acid alleviates cadmium toxicity in barley seedling. Plant Physiol. 132, 272-281.
Mishra, A. and Choudhuri, M.A. (1997) Ameliorating effects of salicylic acid on lead and mercury-induced inhibition of germination and early seedling growth of two rice cultivars. Seed Sci. Tech. 25, 263-270.

Munee, S., Qadri, T.N. and Siddiqi, T.O. (2011) Cytogenetic and biochemical investigation to study the response of Vigna radiata to cadmium stress. Afr. J. Plant. Sci. 5, 183-192.

Nataliya, F. (2015) Use of plant test system for the evaluation of cytogenetic effect of cadmium. The Pharma Innovation Journal, 4(2), 13-15.

Nolan, M.R., Hanson, E., Magnusson, L. and Andersson, B. (2003) Gauging quality in constructivist research: The Aldre Vast Sjuharad model revisited. Quality in Ageing, 4(2), 22-27.

Onyemaobi, O.I., Williams, G.O. and Adekoya, K.O. (2012) Cytogenetic effects of two food preservatives, sodium metabisulphite and sodium benzoate on the root tips of Allium cepa Linn. Life Journal of Science, 14(1), 155-165.

Panda, S.K. and Patra, H.K. (2007) Effect of salicylic acid potentiates cadmium-induced oxidative damage in Oryza sativa L. leaves. Acta Physiol. Plant. 29, 567-575.

Patra, J., Sahoo, M.K. and Panda, B.B. (2005) Salicylic acid triggers genotoxic adaptation to methyl mercuric chloride and ethyl methane sulfonate but, not to malice hydrazide in root meristem cells of Allium cepa L. Mutat Res. 581, 173-180.

Popova, L.P., Maslenkova, L.T., Yordanova, R.Y., Ivanova, A.P., Krantev, A.P., Szalai, G. and Janda, T. (2009) Exogenous treatment with salicylic acid attenuates cadmium toxicity in pea seedlings. Plant Physiol. Biochem. 47, 224-231.

Qian, X.W. (2004) Study on teratogenic effect of potassium dichromate on Vicia faba root tip cells. J. Zhejiang Univ. Sci. B, 26, 337-342.

Qin, R., Jiao, Y.Q., Zhang, S.S., Jiang, W.S. and Liu, D.H. (2010) Effects of aluminum on nucleoli in root tip cells and selected physiological and biochemical characters in Allium cepa var. agrogarum L. BMC Plant Biology, 225, 1471-1482.

Rank, J., Lopez, L.C., Nielsen, M.H. and Moretton, J. (2002) Genotoxicity of maleic hydrazide, acridine 
and DEHP in Allium cepa roots cells performed by two different laboratories. Hereditas, 136(1), 1318.

Rascio, N. and Navari-Izzo, F. (2011) Heavy metal hyperaccumulating plants: How and why do they do it? And what makes them so interesting? Plant Science, 180, 169-181.

Rossman, T.G., Roy, N.K. and Lin, W.C. (1992) Is cadmium genotoxic? IARC Scientific Publications, 118, 367-375.

Sakhabutdinova, A.R., Fatkhutdinova, D.R., Bezrukova, M.V. and Shakirova, F.M. (2003) Salicylic acid prevents damaging action of stress factors on wheat plants. Bulg. J. Plant Physiol. Special issue, 214-219.

Schützendübel, A., Schwanz, P., Teichmann, T., Langenfeld-Heyser, G.K., Godbold, D.L. and Polle, A. (2001) Cadmium-induced changes in antioxidative systems, hydrogen peroxide content, and differentiation in scots pine roots. Plant Physiol. 127, 887-898.

Seoane, A.I. and Dulout, F.N. (2001) Genotoxicity ability of cadmium, chromium and nickel salts studied by kinetochore staining in the cytokinesisblocked micronucleus assay. Mutat. Res. 490, 99106.

Seth, C.S., Misra, V., Chauhan, L.K.S. and Singh, R.R. (2008) Genotoxicity of cadmium on root meristem cells of Allium cepa: cytogenetic and Comet assay approach. Ecotoxicol. Environ. Safety, 71, 711-716.

Shi, Q., Wang, J., Jiang, Z., Wu, H., Wang, J., Jiang, W., Liu, D. and Zou, J. (2017) Effects of cadmium on nucleolus in root tips of Hordeum vulgare. Botanical Sciences., 95(1), 93-102.

Singh, B. and Usha, K. (2003) Salicylic acid induced physiological biochemical changes in wheat seedlings under water stress. Plant Growth Regul. 39, 137-141.

Steinkellner, H., Mun-Sik, K., Helma, C., Ecker, S., Ma, T.H., Horak, O., Kundi, M. and Knasmuller, S. (1998) Genotoxic effects of heavy metals: Comparative investigation with plant bioassays. Environ and Mol. Mutagen, 3, 183-191.

Stohs, S.J., Bagchi, D. Hassoun, E. and Bagechi, M.
(2000) Oxidative mechanisms inb the toxicity of chromium and cadmium ions. J. Environ. Pathol. Toxicol. Oncol. 19, 201-213.

Szepesi, Á., Poor, P., Gémes, K., Horváth, E. and Tari, I. (2008) Influence of exogenous salicylic acid on antioxidant enzyme activities in the roots of salt stressed tomato plants. Acta Biol. Szeged. 52, 199200.

Thangaraja, A., Ganesan, V. and Raja, P. (2013) Cadmium- induced changes in mitotic index and genotoxicity on Vigna unguiculate (Linn) Walp. J. Env. Chem. and Ecotox. 5(3), 57-62.

Umebese, C.E.I., Azeez, T.A. and Adekoya, K.O. (2013) Role of ethylenediamine tetra acetic acid and salicylic acid in alleviating cytogenetic toxicity of copper in roots of Allium cepa (L.). Genetics and Plant Physiology, 3(1-2), 98-108.

Unyayar, S., Celik, A., Cekic, F.C. and Gozel, A. (2006) Cadmium induced genotoxicity, cytotoxicity and lipids peroxidation in Allium sativum and Vicia faba. Mutagenesis, 21, 77-81.

Valverde, O., Noble, F., Beslot, F., Dauge, V., FournieZaluski, M.C. and Roques, B.P. (2001) Delta9tetrahydrocannabinol releases and facilitates the effects of endogenous enkephalins: Reduction in morphine withdrawal syndrome without change in rewarding effect. Eur. J. Neurosci. 13, 1816-1824.

Wahid, F., Shehzad, A., Khan, T. and Kim, Y.Y. (2010) MicroRNAs: Synthesis, mechanism, function, and recent clinical trials. B.B.A. Resaresh, 11, 12311243.

Wang, L.J. and Li, S.H. (2006) Salicylic acidinduced heat or cold tolerance in relation to $\mathrm{Ca}_{2}^{+}$ homeostasis and antioxidant systems in young grape plants. Plant Sci. 170, 685-694.

Wang, Q.L., Zhang, L.T., Zou, J.H., Liu, D.H. and Yue, J.Y. (2014) Effects of cadmium on root growth, cell division and micronuclei formation in root tip cells of Allium cepa var. agrogarum L. Int. JOR. Exp. Bot. 83, 291-298.

Wang, Q.L., Zhang, L.T., Zou, J.H., Liu, D.H. and Yue, J.Y. (2016) The uptake of cadmium by Allium cepa var. agrogarum L. and its effects on chromosome and nucleolar behavior in root tip cells. Int. JOR. Exp. Bot. 85, 155-161. 
Zhang, S.S., Zhang, H.M., Qin, R., Jiang, W.S. and Liu, D.H. (2009) Cadmium induction of lipid peroxidation and effects on root tip cells and antioxidant enzyme activities in Vicia faba L. Ecotoxicology, 18, 814-823.

Zou, J., Yue, J., Jiang, W. and Liu, D. (2012) Effects of cadmium stress on root tip cells and some physiological indexes in Allium cepa var. agrogarum L., Acta Biol. Cracoviensia, Ser. Bot. $54,129-141$.

(Received 28/ 2/2018;

accepted 25/ 6/2018)

تحفيز نبات حبة البركة للتأقلم مع السمية الوراثية للكادميوم بواسطة حمض الساليسيلك

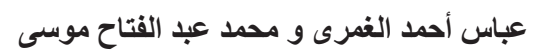
قسم النبات والميكروبيولوجى ـ كلية العلوم - جامعة الأزهر - القاهرة - مصر.

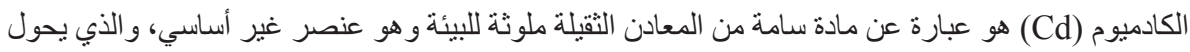

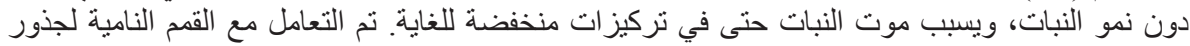

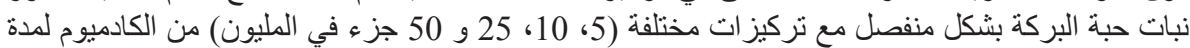

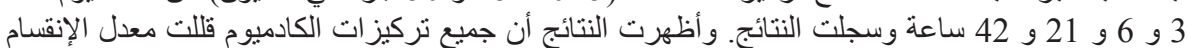

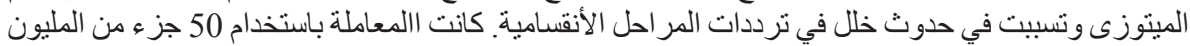

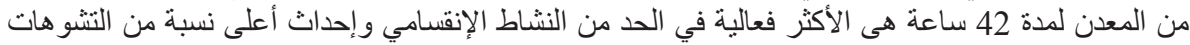

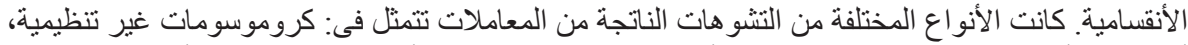

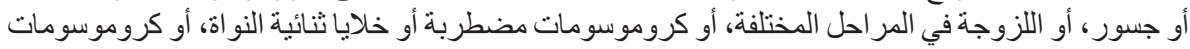

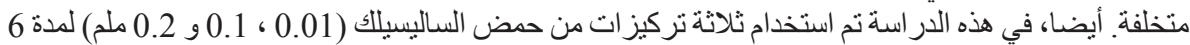

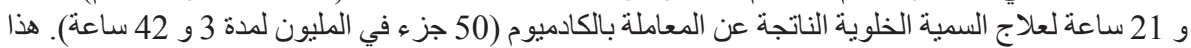

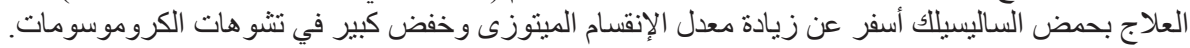

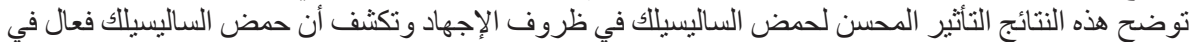

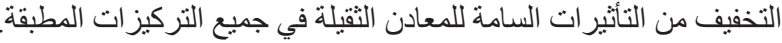

